\title{
Utilization of Cinnamon, Clove and Thyme Essential Oils as Antimicrobial and Bioactive Compounds in Kishk Manufacturing
}

\author{
Elsayed A. Mahmoud ${ }^{* a}$, Abd-Ellah A. Abd-Alla ${ }^{b}$ and Khaled H. Salman ${ }^{* c}$ \\ ${ }^{a}$ Department of Food Science and Nutrition, Faculty of Agriculture, Sohag University, Sohag, Egypt. \\ ${ }^{\mathrm{b}}$ Department of Dairy Sciences, Faculty of Agriculture, Sohag University, Sohag, Egypt. \\ ${ }^{c}$ Department of Dairy Science, Faculty of Agriculture, Al-Azhar University at Assuit, Assuit, Egypt.
}

Received: $5 / 11 / 2020$

\begin{abstract}
Cinnamon, clove and thyme essential oils (EOS) were used to manufacture of Kishk product for owns preservation effect and biological \& nutritive values. EOS-kishk was prepared by adding various concentrations of essential oils $(100$ and $200 \mathrm{mg} / \mathrm{kg}$ ) to traditional kishk mixtures. Results showed that cinnamon, clove and thyme essential oils were having 11, 32 and 18 identified compounds by using GC-MS, respectively. EOS-kishk samples contained (20.44-24.74\%) protein, (5.13-5.80\%) ash and (4.64 to $6.57 \%$ ) moisture. The titratable acidity (TA \% as lactic acid) and $\mathrm{pH}$ in the kishk samples ranged from 1.72 to $2.12 \%$ and $4.92-5.12$, respectively. The water holding capacity (WHC) of the EOS-kishk samples varied from 464.10 to $498.48 \mathrm{~g} / \mathrm{kg}$, which was significantly higher than those of the control sample. EOS-Kishk samples had the highest antioxidant activity values $(40.69 \%)$ at $200 \mathrm{mg} / \mathrm{kg}$ thyme oil compared with the control ones (31.54\%). Mineral amounts of EOS-kishk had a slight change among all treatments. Microbiologically, the total viable bacterial count in most samples was slightly decreased as well as Lactobacilli, Streptococci and spore forming bacteria counts when compared with control. Whilst, there were notably decrease on coliform bacteria as well as yeast and mold counts in the EOS-kishk samples when compared with control. Overall, EOS-kishk has highly nutritional and biological value.
\end{abstract}

Keywords: Kishk, essential oils, bioactive components, functional properties, antioxidant activity, microbiological quality

\section{INTRODUCTION}

Traditional kishk is one of the common foods in Upper Egypt. It is a healthy, natural and has a great flavor and cultural values that are increasingly attractive to the Egyptian. The main ingredients of Kishk are Zeer-milk with boiled, dried and crushed whole wheat grains (Bulgur). It is rich in nutritive constituents and source for many vitamins, growth factors and other nutrients (Anon, 2007). Fermentation may be increased the nutritional value of dairy-cereal blends by decreasing the content of antinutritional factors, such as phytic acid, thereby increasing inorganic bioavailability (Poutanen et al., 2009); also, by increasing the content of bioactive components (Rahmawati and Suntornsuk, 2016). The sensory quality, composition and nutritional properties of kishk can be varied by changing the starter culture, type of cereal and the ratio of dairy constituent used in the formula (Gadallahand Hassan, 2019; Demirci et al., 2019). Essential oils (EOS) are aromatic and important sources of new phytochemical agents that improve physicochemical, organoleptic properties, nutritional values, harmless for human, have shown positive health effects and shelf-life of food products (Sadrizadeh et al., 2018). The formation of EOS varied highly and can be contained a mixture of a small terpenes up to highly complex blend (terpenes, esters, aromatic hydrocarbons, phenols and other natural substances), and their diverse properties are possibly concerning to their role in plant survival (Probst, 2012). EOS included bioactive compounds that allowed antioxidant and antimicrobial activity due to the existence of phytochemicals (Pozzatti et al., 2009). Although, in case of EOS are used to change aroma, they are not being regard as food added ingredients. The use of seasoning agents is allowed in agreement with good manufacturing practices (EU, 2008). Also, EOS is categorized as generally recognized as safe (GRAS) (Burt, 2004). Antimicrobial activity of EOS differed with type, composition of plant, concentration of EOS, the tested microorganism, processing and storage conditions (Marino et al., 2001; Ozogul et al., 2015). The cinnamon essential oil is a normal oily extracted from cinnamon and mostly made up of diverse active components such as cinnamic aldehyde, cinnamic acid and eugenol, where cinnamaldehyde is a main component of cinnamon essential oil (Xing et al., 2014). Cinnamon essential oil and cinnamic aldehyde have been found to have excellent antibacterial activities against a numerous pathogenic microorganisms regarding food borne illness and most used as antioxidant and antimicrobial agents in preservation of foods (Xing et al., 2014; Chen et al., 2016; Zhang et al., 2016; Han et al., 2018; Kaliamurthi et al., 2019). Clove essential oil (CLEO Syzygium aromaticum L.) is a normal oil and seasoning agent with excellent antioxidant and antimicrobial properties is an efficient, safe, colorant, natural preservative, and spice in various food products, CLEO has bioactive components such as caryophyllene, eugenol, triterpenes, and sesquiterpenes (Ramadan et al., 2013; Aguilar-González et al., 2015; Hasheminejad et al., 2019). Also, CLEO has various applications in food preservation, biomedical, pharmaceutical, sanitary, cosmetics industries and active packaging (Chen et al., 2017). Thyme (Thymus vulgaris $\mathrm{L}$.) essential oil displayed significant muscle relaxant, antimicrobial and antioxidant activity (Rota et al., 2008; Grigore et al., 2010). Thyme is usually used in production of beautifying products, perfumes, soaps and cosmetic industries (Schulz et al., 2003). When essential oil of thyme is used as a food additive, it 
should be categorized on the food package as a food additive (EU, 2008). The aim of this study was to evaluate the use of some essential oils for improving the quality, antimicrobial, antioxidant, nutritional status and health benefits of traditional kishk.

\section{MATERIALS AND METHODS}

\section{Materials:}

Dry Wheat grains (Triticum spp.) were purchased from local market (Sohag, Egypt). Zeer-milk was obtained from local rural houses (Sohag, Egypt). Commercial sodium chloride was obtained from ElNasr Saline's Company (Alexandria, Egypt). EOS of cinnamon (Cinnamomum zeylanicum), clove (Syzygium aromaticum) and thyme (Thymus vulgaris) were purchase from Natural oil extraction unit, National Research Centre, Cairo, Egypt.

Manufacture of Kishk: Kishk samples were prepared according to Tamime et al. (1997) with some modifications as following:

Wheat was sorted from damaged grain, cleaned from extraneous and boiled for $60 \mathrm{~min}$ in hot water.

Air-dried, (for 2-3 days under aseptic conditions), then cracked to small debris (Bulgur)
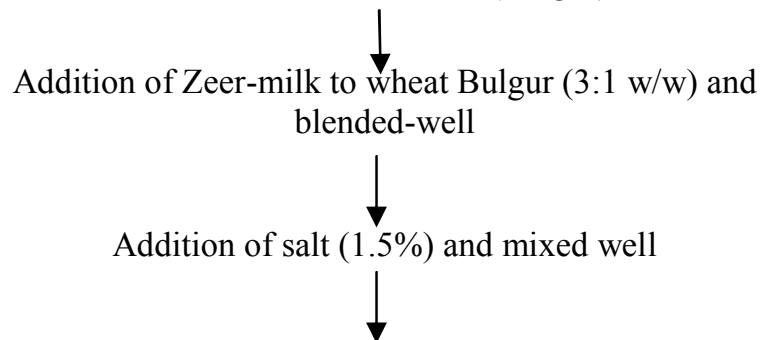

The mixture was divided into seven equal portions Addition of essential oils as follow:

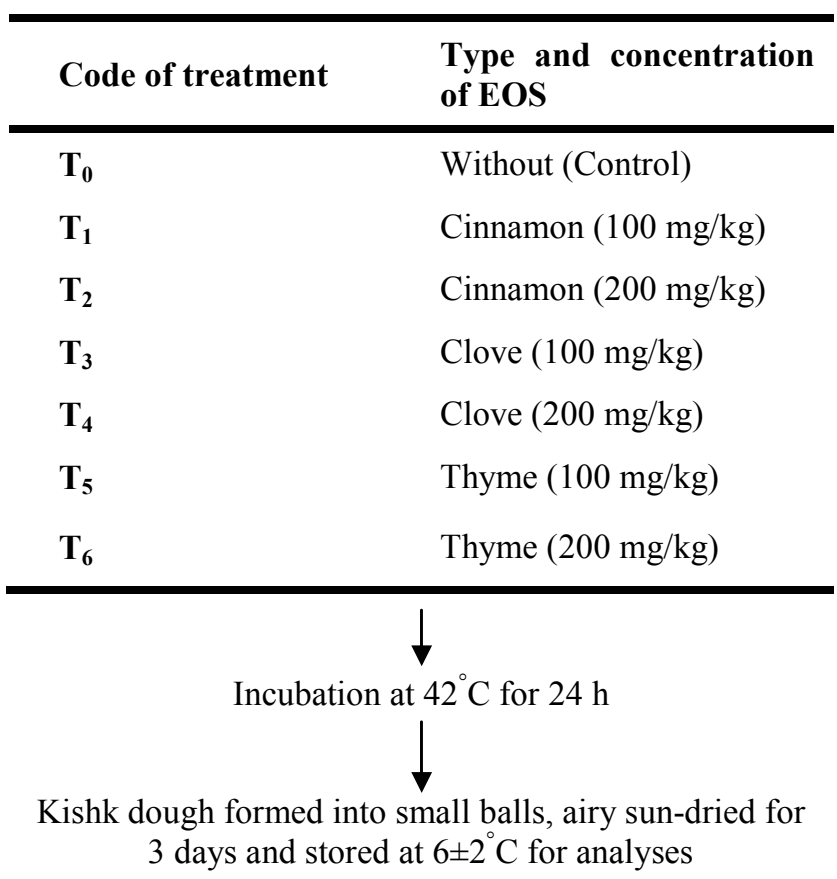

Fig. (1): Scheme diagram for kishk manufacture

\section{Methods of analyses:}

Moisture content was determined according to IDF (1987), Titratable acidity (as lactic acid\%) was carried out according to AOAC (2000). The $\mathrm{pH}$ values were measured using a pH meter (model 68 ESD 19713), USA. Ash was determined according to AOAC (2007). Total nitrogen (TN) contents was determined as described by IDF (1993). Potassium and sodium content estimated by Flame Photometer (BWB XP Flame Photometer Technologies, UK LTD) according to Page (1982). Phosphorus content was determined according to Tiessen and Moir (1993). Calcium content was estimated by Flame Photometer according to Villanueva et al. (2000). Water holding capacity (WHC) was carried out according to Shevade et al. (2019). The 2,2Diphenyl-1-picrylhydrazyl (DPPH) assay was carried out according to the method described by Lee et al. (2003).

\section{Gas chromatography-MS (GC-MS):}

The chemical composition of EOS was performed using Trace GC-TSQ Quantum mass spectrometer (Thermo Scientific, Austin, TX, USA) with a direct capillary column TG-5MS (30 m x $0.25 \mathrm{~mm} \times 0.25 \mu \mathrm{m}$ film thickness). The column oven temperature was initially held at $50^{\circ} \mathrm{C}$, then increased by $5^{\circ} \mathrm{C} / \mathrm{min}$ to $200^{\circ} \mathrm{C}$ hold for $2 \mathrm{~min}$ and increased to the final temperature $300^{\circ} \mathrm{C}$ by $30^{\circ} \mathrm{C} / \mathrm{min}$ and hold for $2 \mathrm{~min}$. The injector and MS transfer line temperatures were kept at $260,260^{\circ} \mathrm{C}$, respectively; Helium was used as a carrier gas at a constant flow rate of $1 \mathrm{ml} / \mathrm{min}$. The solvent delay was $3 \mathrm{~min}$ and diluted samples of $1 \mu \mathrm{l}$ were injected automatically using Autosampler AS1300 coupled with GC in the split mode. EI mass spectra were collected at $70 \mathrm{eV}$ ionization voltages over the range of $\mathrm{m} / \mathrm{z} 50-650$ in full scan mode. The ion source temperature was set at $200^{\circ} \mathrm{C}$. The components were identified by comparison of their retention times and mass spectra with those of WILEY 09 and NIST 11 mass spectral database.

\section{Microbiological analyses:}

The total viable bacterial count was determined according to Marshal (1992). Lactobacilli count was estimated on the selective medium for lactobacilli (MRS) and streptococci count on M17 agar medium respectively IDF (1997). Coliform bacteria were enumerated according to IDF (1985). Moulds \& Yeasts were enumerated according to FDA (2002). Spore forming bacterial count was determined according to APHA (1992).

\section{Sensory evaluation:}

Organoleptic evaluation of prepared Kishk samples was carried out according to the scheme of Clark et al. (2009), the samples were subjected to organoleptic analysis by sixteen well-trained members of the Food Science and Nutrition Department, Dairy Sciences Department (Fac. of Agric. Sohag Univ., Egypt). The evaluated sensory attributes were: Flavor (1-10 points), body and texture (1-5 points) and appearance and color (1-5 points). 


\section{Statistical Analysis:}

Analysis of variance was performed on the data using the software program; JMP Student Edition for Windows and Macintosh (The User's Guide to Statistics with JMP Student Edition, SAS Institute, 2009).

\section{RESULTS AND DISCUSSIONS}

Chemical characteristics of cinnamon essential oil:

Cinnamon essential oil was fractionated and identified by GC/MS as shown in Table (1). From these data, it is apparent that there were 11 identified volatile compounds in cinnamon oil as a relative concentration varied from 0.97 to $52.90 \%$. Furthermore, the major constituent of cinnamon essential oil was cinnamaldehyde $(52.90 \%)$ followed by Trans-13Octadecenoic acid (23.99\%), 9, 12-Octadecadienoic acid $(5.91 \%), \alpha$-copaene $(4.45 \%)$ and $\mathrm{N}$-Hexadecanoic acid $(3.06 \%)$. These results are agreed with some previous studies but there were some differences in the content of each component, Jiang et al. (2020) found that the major component of cinnamon essential oil was cinnamaldehyde (67.25\%). Jayawardena and Smith (2010), Şimşek et al. (2013); Jeon et al. (2017) they reported that, the cinnamaldehyde as major component of cinnamon oil extracted by different methods was $68.95,80.0$ and $88.2 \%$. The identified components were commonly found in cinnamon essential oil, but with different levels depending on the genetic, differing chemo type, geographic origin, season, environmental factors, drying and extraction methods (Jiang et al., 2020).

Table (1): The identified compounds of cinnamon (Cinnamomum zeylanicum) essential oil

\begin{tabular}{llcc}
\hline Peak No. & Compound name & Rt (min) & Rp(\%) \\
\hline $\mathbf{1}$ & Cyclohexene & 6.06 & 2.73 \\
$\mathbf{2}$ & a-copaene & 12.43 & 4.45 \\
$\mathbf{3}$ & Cinnamaldehyde & 14.16 & 52.90 \\
$\mathbf{4}$ & À-Muurolene & 15.37 & 1.52 \\
$\mathbf{5}$ & Naphthalene & 15.88 & 1.75 \\
$\mathbf{6}$ & N-Hexadecanoic acid & 22.66 & 3.06 \\
$\mathbf{7}$ & Trans-13-Octadecenoic acid & 25.51 & 23.99 \\
$\mathbf{8}$ & 9,12- Octadecadienoic acid & 25.68 & 5.91 \\
$\mathbf{9}$ & Hexadecanoic acid, 3- & 28.71 & 1.02 \\
$\mathbf{1 0}$ & [(trimethylsilyl)oxy] propyl ester & 30.89 & 1.69 \\
$\mathbf{1 1}$ & Hydrocinnamic acid & 31.12 & 0.97 \\
\hline
\end{tabular}

\section{Chemical characteristics of clove essential oil:}

Clove essential oil was fractionated and identified using GC/MS and the results are shown in Table (2). From these data it could be noticed that the identified representing compounds were 32 . The level of these compounds varied between 0.07 and $78.22 \%$. The major identified compound was Oxabicyclo [4.1.0]heptan-2one, 3-methy7 (6-1-methylethyl) (78.22\%) followed by Caryophyllene $\quad(7.25 \%), \quad 2-C y c l o h e x e n-1-o n e, \quad 2-$ hydroxy-3-methyl-6-(1-methylethyl) (3.44\%), Tau.cadinol (1.69\%), 1,6-cyclodecadiene, 1-methyl-5methylene-8-(1-methylethyl) (1.41\%) and Octadien-3ol, 2,4,4,7-tetramethyl 5,7- $(1.35 \%)$. These are in agreement with $\mathrm{Yu}$ et al. (2017) reported that clove essential oil consisted of eugenol (44.88\%) and caryophyllene (26.53\%). Saricaoglu and Turhan (2019) clove essential oil contained cymol (26.29\%), $\alpha$-pinene (20.65\%), eugenol (17.02\%) and 3-carene (11.62\%) were predominant compounds. These differences could be attributed to such factors as genetic, age and stage of maturity, drying method, weather conditions, soil composition, type of plant parts and extraction conditions (Noori et al., 2018).

\section{Chemical characteristics of thyme essential oil:}

Thyme essential oil was fractionated and identified using GC/MS and the results as shown in
Table (3). It could be noticed that 18 compounds were identified. The identified compounds percentage ranged from 0.49 to $28.88 \%$ of total thyme essential oil. The major identified compound was 9Octadecenoic acid, (E) (28.88\%) followed by Phenol (18.46\%), Isopropyl-5-methylcyclohexa2-1 (14.22\%), 9,12-Octadecadienoic acid (10.12\%), Ethylidene-2,2dimethyl3-butyn-2-ol (7.92\%), N-Hexadecanoic acid $(4.85 \%)$, Benzene (3.45\%), Thymoquinone $(2.04 \%)$, Nonacosatriynoic acid (1.86\%) and Trimethyl-2(butylthio) cycloheptatriene (1.34\%) of total thyme essential oil. These components are responsible for biological activity of thyme essential oil, these results are in harmony with Alsaraf et al. (2020). Saricaoglu and Turhan (2019) found that the main compounds in thyme essential oil were cymol $(25.07 \%)$, $\alpha$-pinene $(17.0 \%)$, acetophenone $(12.52 \%)$ and $\gamma$-terpinene (12.21\%). Oliveiraa et al. (2020) reported that 28 compounds were identified in thyme essential oil, with thymol $(50.5 \%)$, p-Cymene $(19.4 \%)$ and $\gamma$-Terpinene $(9.1 \%)$ as the most abundant components. The differences in chemical composition of essential oil are depended on various factors including time of collection, environment and cultivation methods, drying method and part of plant for distillation (Hudaib and Aburjai, 2007). 
Table (2): The identified compounds of clove (Syzygium aromaticum) essential oil

\begin{tabular}{|c|c|c|c|}
\hline Peak No. & Compound name & Rt (min) & $\operatorname{Rp}(\%)$ \\
\hline 1 & Bicyclo [3.1.1] heptane, 6,6-dimethyl-2-methylene & 4.06 & 0.45 \\
\hline 2 & 3-Octanol, acetate & 7.30 & 0.32 \\
\hline 3 & 2-Hexenoic acid, 3,4,4 trimethyl-5-oxo & 11.67 & 1.27 \\
\hline 4 & 5,7Octadien-3-ol, 2,4,4,7-tetramethyl & 11.74 & 1.35 \\
\hline 5 & Oxabicyclo[4.1.0]heptan-2-7one, 3-methyl-(6-1-methylethyl) & 12.69 & 78.22 \\
\hline 6 & 2-Cyclohexen-1-one, 2-hydroxy-3-methyl-6-(1-methylethyl) & 13.15 & 3.44 \\
\hline 7 & Isopropyl-7-methyl-nona-3,5-7diene-2,8-dione & 13.38 & 0.11 \\
\hline 8 & Caryophyllene & 13.82 & 7.25 \\
\hline 9 & Á-Famesene & 14.03 & 0.31 \\
\hline 10 & Cycloundecatriene-1,4,8, 2,6,6,9-tetramethyl & 14.43 & 0.84 \\
\hline 11 & 5-allyl-2-methoxyphenol & 14.59 & 0.09 \\
\hline 12 & 1,6-cyclodecadiene, 1-methyl-5-methylene-8-(1-methylethyl) & 14.91 & 1.41 \\
\hline 13 & Isoledene & 15.16 & 0.10 \\
\hline 14 & Naphthalene & 15.51 & 0.46 \\
\hline 15 & Carotol & 15.60 & 0.24 \\
\hline 16 & $\begin{array}{l}\text { 5,5-Dimethyl-6-(3-methyl-buta-1,3-dienyl)-7-oxa-bicyclo [4.1.0] } \\
\text { hept-1-yl]-methanol }\end{array}$ & 15.84 & 0.12 \\
\hline 17 & (2E,4S,7E)-4-Isopropyl-1,7-dimethylcyclodeca-2,7-dienol & 16.73 & 0.20 \\
\hline 18 & Caryophyllene oxide & 17.23 & 0.30 \\
\hline 19 & Epicubenol & 17.48 & 0.29 \\
\hline 20 & Tau.-cadinol & 18.05 & 1.69 \\
\hline 21 & Caryophylla-4(12),8(13)-dien-5à-ol & 18.23 & 0.14 \\
\hline 22 & Methoxyimidazo[1,5-5a]quinoline & 18.29 & 0.11 \\
\hline 23 & À-Cadinol & 18.35 & 0.07 \\
\hline 24 & Ledene oxide & 19.04 & 0.08 \\
\hline 25 & 2-Pentadecanone, 6,10,14-trimethyl & 19.42 & 0.11 \\
\hline 26 & Phytol & 22.82 & 0.14 \\
\hline 27 & 1-naphthalenepropanol & 23.34 & 0.12 \\
\hline 28 & Benzoic acid, 2-[4-(1,1-dimethylethyl) phenoxy] & 23.47 & 0.27 \\
\hline 29 & 1,3-cyclopentadiene butanenitrile & 24.64 & 0.18 \\
\hline 30 & 9-octadecenamide & 27.39 & 0.07 \\
\hline 31 & Pentatriacontane & 27.63 & 0.10 \\
\hline 32 & Hexatriacontane & 29.45 & 0.15 \\
\hline
\end{tabular}


Table (3): The identified compounds of thyme (Thymus vulgaris) essential oil

\begin{tabular}{|c|c|c|c|}
\hline Peak No. & Compound Name & Rt (min) & $\operatorname{Rp}(\%)$ \\
\hline 1 & Cyclohexanol & 6.07 & 1.30 \\
\hline 2 & Benzene & 6.58 & 3.45 \\
\hline 3 & Isopropyl-5-methylcyclohexa 2-1 & 9.58 & 14.22 \\
\hline 4 & Thymoquinone & 12.50 & 2.04 \\
\hline 5 & Ethylidene-2,2-dimethyl3-butyn-2-ol & 13.03 & 7.92 \\
\hline 6 & Phenol & 13.29 & 18.46 \\
\hline 7 & Trimethyl-2- 2,5,5 (butylthio) cycloheptatriene & 14.09 & 1.34 \\
\hline 8 & N-Hexadecanoic acid & 22.68 & 4.85 \\
\hline 9 & 10-Octadecenoic acid, methyl ester & 24.28 & 0.49 \\
\hline 10 & Linoleic acid ethyl ester & 24.50 & 0.56 \\
\hline 11 & 9-Octadecenoic acid, (E) & 25.55 & 28.88 \\
\hline 12 & 9,12-Octadecadienoic acid & 25.72 & 10.12 \\
\hline 13 & Hexadecanoic acid, 3-[(trimethylsilyl)oxy] propyl ester & 28.72 & 1.17 \\
\hline 14 & Nonacosatriynoic acid & 30.89 & 1.86 \\
\hline 15 & 2-Oleoylglycerol, 2TMS derivative & 31.12 & 1.31 \\
\hline 16 & Isochiapin $b$ & 31.65 & 0.42 \\
\hline 17 & $\begin{array}{l}\text { Trimethyl-3-(3,8,12,16-2,2,4 tetramethyl-heptadeca- } \\
\text { 3,7,11,15-tetraenyl)-cyclohexanol }\end{array}$ & 32.34 & 0.94 \\
\hline 18 & Alpha-tocopherol (vitamin e) & 36.83 & 0.68 \\
\hline
\end{tabular}

Table (4): Major components in EOS used

\begin{tabular}{lccccc}
\hline Cinnamon & \multicolumn{2}{c}{ Clove } & \multicolumn{2}{c}{ Thyme } \\
\hline Commercial name & Rp (\%) & Commercial name & Rp (\%) & Commercial name & Rp (\%) \\
\hline Cinnamaldehyde & 52.90 & Diosphenol (Camphor) & 78.22 & Petroselic acid & 28.88 \\
Petroselic acid & 23.99 & Isocaryophyllene & 7.25 & Phenol & 18.46 \\
Linoelaidic acid & 5.91 & Ascaridol & 3.44 & Menthol & 14.22 \\
Isocaryophyllene & 4.45 & Cedrelanol & 1.69 & Linoelaidic acid & 10.12 \\
Hexadecanoic-d31 acid & 3.06 & beta-Caryophyllen & 1.41 & Benzylurea & 7.92 \\
\hline
\end{tabular}

\section{Gross chemical composition EOS-kishk:}

The chemical composition of kishk samples is present in Table (5). Protein content ranged from 20.44 to $24.74 \%$. Kishk samples contained clove essential oil at 100 and $200 \mathrm{mg} / \mathrm{kg}$ showed highest protein content (24.74 and $23.80 \%$, respectively) compared with the control sample $\mathrm{T}_{0}(21.02 \%)$, these results are in agreed with Sadrizadeh et al. (2018), they found that EOS have phytochemical agents that improve physicochemical, organoleptic properties and nutritional values. The protein content of all kishk samples were higher than in previous studies and exceeds the requirements, outlined by the World Food Program (WFP) for wheat soy blend (WSB) which should contain a minimum of $16 \%$ protein (World Food Program, 2015). Ash content ranged from 5.13 to $5.80 \%$, where $\mathrm{T}_{0}$ sample showed the highest value $(5.80 \%)$. EOS-Kishk samples blend with various essential oils showed approximate levels of ash content. The moisture content of kishk samples decreased by the addition of essential oils compared to the control sample. The sample $\mathrm{T}_{1}$ contained $100 \mathrm{mg}$ cinnamon essential oil $/ \mathrm{kg}$ had the lowest moisture content $(4.81 \%)$ compared to the control sample $(6.57 \%)$. Also, the moisture content of kishk samples decreased by increasing the concentration of essential oils added. Tamime et al. (1999) found that the moisture content in kishk samples ranged from 6.8 to $10.8 \%$, and ash levels from 4.1 to $9.4 \%$, thus, this minor variance in the moisture content is foremost linked to the composition of the ingredients used in kishk formulations and the drying technique (Erkan et al., 2006). 
Table (5): Gross chemical composition of EOS-Kishk

\begin{tabular}{|c|c|c|c|}
\hline Treatments of kishk & Protein \% (dwb) & $\operatorname{Ash} \%(d w b)^{*}$ & Moisture \% \\
\hline $\mathbf{T}_{0}($ Control $)$ & $21.02 \pm 0.646^{\mathrm{bc}}$ & $5.80 \pm 0.043^{\mathrm{a}}$ & $6.57 \pm 0.252^{\mathrm{a}}$ \\
\hline$T_{1}($ Cinnamon 100 mg/kg) & $21.74 \pm 0.700^{\mathrm{b}}$ & $5.28 \pm 0.337^{\mathrm{c}}$ & $4.81 \pm 0.153^{\mathrm{cd}}$ \\
\hline $\mathrm{T}_{2}($ Cinnamon $200 \mathrm{mg} / \mathrm{kg})$ & $21.40 \pm 0.00 \mathrm{~b}^{\mathrm{c}}$ & $5.13 \pm 0.038^{\mathrm{c}}$ & $4.64 \pm 0.562^{d}$ \\
\hline$T_{3}($ Clove $100 \mathrm{mg} / \mathrm{kg})$ & $24.74 \pm 0.336^{\mathrm{a}}$ & $5.74 \pm 0.006^{\mathrm{a}}$ & $5.84 \pm 0.510^{b}$ \\
\hline $\mathrm{T}_{4}($ Clove $200 \mathrm{mg} / \mathrm{kg})$ & $23.80 \pm 0.782^{\mathrm{a}}$ & $5.40 \pm 0.331^{\mathrm{bc}}$ & $5.34 \pm 0.329^{\mathrm{bc}}$ \\
\hline$T_{5}($ Thyme 100 mg/kg) & $21.34 \pm 1.176^{\mathrm{bc}}$ & $5.68 \pm 0.136^{a b}$ & $5.01 \pm 0.239^{\mathrm{cd}}$ \\
\hline $\mathrm{T}_{6}$ (Thyme $200 \mathrm{mg} / \mathrm{kg}$ ) & $20.44 \pm 0.312^{c}$ & $5.69 \pm 0.056^{\mathrm{ab}}$ & $4.93 \pm 0.225^{\mathrm{cd}}$ \\
\hline LSD & 1.1679 & 0.3297 & 0.6205 \\
\hline
\end{tabular}

*dwb: On dry weight basis

Means of triplicates

Means having the same letter within each column are not significantly different at $p=0.05$

\section{Physicochemical properties of EOS-kishk samples:}

\section{The titratable acidity (TA\%) and $\mathrm{pH}$ :}

The titratable acidity ( $\%$ as lactic acid) and $\mathrm{pH}$ values of Kishk samples are presented in Table (6). The $\mathrm{TA} \%$ in the kishk samples ranged from 1.72 to $2.12 \%$. Kishk samples which contained cinnamon 100,200 $\mathrm{mg} / \mathrm{kg}$ and clove $100 \mathrm{mg} / \mathrm{kg}$, had significantly $(\mathrm{P}<0.05)$ higher than either samples. Furthermore, Kishk blended with thyme $200 \mathrm{mg} / \mathrm{kg}$ had the highest $\mathrm{pH}$ value (5.12) while, the lowest value (4.92) observed in the sample contained cinnamon $100 \mathrm{mg} / \mathrm{kg}$. Thus, there was variable in the TA and $\mathrm{pH}$ values in Kishk samples. These results could be attributed to the differences of the major substance found in the essential oils. From these results, it can be concluded that the essential oils had a specified effect on the kishk fermentation; these results were in same line with other studies (Mahmoudi et al., 2014).

\section{Water holding capacity (WHC):}

The WHC is indicative of an increase in water absorption and swelling of the reconstituted powder (particles) during stirring and heating, and hence is likely to impact on the viscosity of the resultant soup/porridge (Wani et al., 2012). WHC for kishk samples were presented in Table (6). There were significant differences $(\mathrm{P}<0.05)$ in WHC of kishk samples treated with essential oils and the control $\left(\mathrm{T}_{0}\right)$. The WHC in the kishk samples ranged from 464.10 to 498.48 pellet, $\mathrm{g} / \mathrm{kg}$. Also, WHC increased with essential oils concentration from 100 to $200 \mathrm{mg} / \mathrm{Kg}$. Kishk samples contained clove essential oil at $200 \mathrm{mg} / \mathrm{kg}$ showed highest WHC (498.48 pellet, g/kg) compared with the control sample $\mathrm{T}_{0}(464.10$ pellet, $\mathrm{g} / \mathrm{kg})$. The WHC was also likely to be influenced by some factors, other than starch content, such as starch granule dimensions, relative proportions of amylose-to-amylopectin, and the presence of other components including lipids, proteins, salt, and acids, and their interactive effects (Kett et al., 2013; Kumar et al., 2018). The variable interactive effects may be occurred between the components of kishk mixture and the kind of additive EOS which affected the WHC values.

\section{Antioxidant activity of EOS- kishk:}

DPPH characteristics of kishk samples showed significant differences when using some types of essential oils (Table 6). Kishk samples blended with essential oils had the highest antioxidant activity values compared with control sample $\left(\mathrm{T}_{0}\right)$. The addition of thyme essential oil at $200 \mathrm{mg} / \mathrm{kg}$ to kishk $\left(\mathrm{T}_{6}\right)$ had the highest DPPH radical scavenging value $(40.69 \%)$. The DPPH radical scavenging values of kishk samples increased by increasing the level of the added essential oils. These results could be attributed to the differences of phenolic compounds in essential oils. These results are in harmony with El-Den (2020), which found that probiotic kishk containing $0.3 \%$ olive leaves extract had the highest antioxidant value followed by that containing 0.2 and $0.1 \%$ olive extract, respectively. Kishk containing $0.3 \%$ moringa extract had DPPH radical scavenging values higher than those containing 0.1 and $0.2 \%$ moringa extract, respectively. 
Table (6): Physicochemical properties of EOS-kishk samples

\begin{tabular}{|c|c|c|c|c|}
\hline Treatments of kishk & $\begin{array}{c}\text { Titratable acidity } \\
\text { TA } \%\end{array}$ & pH & WHC pellet, g/kg & DPРH \% \\
\hline $\mathbf{T}_{0}($ Control $)$ & $1.88 \pm 0.084^{b}$ & $4.94 \pm 0.015^{\mathrm{de}}$ & $464.10 \pm 1.408^{b}$ & $31.54 \pm 0.343^{\mathrm{e}}$ \\
\hline$T_{1}($ Cinnamon $100 \mathrm{mg} / \mathrm{kg})$ & $2.07 \pm 0.030^{\mathrm{a}}$ & $4.92 \pm 0.020^{\mathrm{e}}$ & $492.20 \pm 3.992^{\mathrm{a}}$ & $32.42 \pm 0.175 \mathrm{~d}$ \\
\hline$T_{2}($ Cinnamon $200 \mathrm{mg} / \mathrm{kg})$ & $2.09 \pm 0.030^{\mathrm{a}}$ & $5.00 \pm 0.010^{c}$ & $495.16 \pm 3.011^{\mathrm{a}}$ & $32.76 \pm 0.066^{\mathrm{d}}$ \\
\hline $\mathrm{T}_{3}($ Clove $100 \mathrm{mg} / \mathrm{kg})$ & $2.12 \pm 3.011^{\mathrm{a}}$ & $4.97 \pm 0.040^{\mathrm{cd}}$ & $484.52 \pm 14.94^{\mathrm{a}}$ & $30.69 \pm 0.286^{\mathrm{f}}$ \\
\hline $\mathrm{T}_{4}($ Clove $200 \mathrm{mg} / \mathrm{kg})$ & $1.78 \pm 0.040^{\mathrm{c}}$ & $5.06 \pm 0.010^{b}$ & $498.48 \pm 8.630^{\mathrm{a}}$ & $35.39 \pm 0.238^{\mathrm{c}}$ \\
\hline$T_{5}($ Thyme $100 \mathrm{mg} / \mathrm{kg})$ & $1.79 \pm 0.050^{\mathrm{c}}$ & $5.04 \pm 0.015^{b}$ & $486.70 \pm 17.81^{\mathrm{a}}$ & $38.06 \pm 0.686^{\mathrm{b}}$ \\
\hline$T_{6}$ (Thyme $200 \mathrm{mg} / \mathrm{kg}$ ) & $1.72 \pm 0.00^{\mathrm{c}}$ & $5.12 \pm 0.010^{\mathrm{a}}$ & $494.76 \pm 5.334^{\mathrm{a}}$ & $40.69 \pm 0.114^{\mathrm{a}}$ \\
\hline LSD & 0.092 & 0.0347 & 17.137 & 0.5823 \\
\hline
\end{tabular}

Means of triplicates

Means having the same letter within each column are not significantly different at $p=0.05$

\section{Minerals content of EOS-kishk samples:}

The concentrations of $\mathrm{Na}, \mathrm{K}, \mathrm{Ca}$ and $\mathrm{P}$ of EOSKishk samples were shown in Table (7). It was clear that samples contained clove essential oil (100 and 200 $\mathrm{mg} / \mathrm{kg}$ ) had the highest content of $\mathrm{Na}$ (1945.17 and $1894.43 \mathrm{mg} / 100 \mathrm{~g}$ ) and $\mathrm{K}(542.78$ and $544.50 \mathrm{mg} / 100 \mathrm{~g})$, respectively. Whereas, the sample contained clove essential oil at $100 \mathrm{mg} / \mathrm{kg}$ given high Ca content (547.42 $\mathrm{mg} / 100 \mathrm{~g}$ ) compared with other Kishk samples. In addition, samples contain clove essential oils (100 $\mathrm{mg} / \mathrm{kg}$ ) had the highest amount of P (371.9 mg/100g) followed by (328.9 $\mathrm{mg} / 100 \mathrm{~g})$ in the sample contained clove essential oil $200 \mathrm{mg} / \mathrm{kg}$. While, $\mathrm{T}_{5}$ sample contained thyme $100 \mathrm{mg} / \mathrm{kg}$ had the lowest amount of phosphorus $(259.2 \mathrm{mg} / \mathrm{kg})$. The levels of potassium and calcium were approximated in most of the experimental treatments. All Kishk samples in this study surpassed on the specifications of the WFP which recommends that fortified blended foods (Super cereal plus) should contain calcium at concentrations of $362 \mathrm{mg} / 100 \mathrm{~g}$ (WFP, 2015).

Table (7): Minerals profile (mg/100g) of EOS-kishk samples

\begin{tabular}{|c|c|c|c|c|}
\hline Treatments of kishk & $\mathbf{N a}$ & $\mathbf{K}$ & $\mathbf{C a}$ & $\mathbf{P}$ \\
\hline$T_{0}$ (Control) & $1807.90 \pm 3.001^{\mathrm{c}}$ & $512.77 \pm 6.444^{\mathrm{bc}}$ & $508.61 \pm 2.882^{b c}$ & $300.4 \pm 1.90^{\mathrm{cd}}$ \\
\hline$T_{1}($ Cinnamon $100 \mathrm{mg} / \mathrm{kg})$ & $1840.29 \pm 8.189^{b c}$ & $530.32 \pm 1.926^{\mathrm{ab}}$ & $520.58 \pm 2.069^{b}$ & $305.0 \pm 2.11^{\mathrm{c}}$ \\
\hline $\mathrm{T}_{2}($ Cinnamon $200 \mathrm{mg} / \mathrm{kg})$ & $1868.90 \pm 74.46^{\mathrm{b}}$ & $537.10 \pm 24.41^{\mathrm{a}}$ & $506.59 \pm 6.104^{c}$ & $293.7 \pm 6.24^{d}$ \\
\hline$T_{3}($ Clove $100 \mathrm{mg} / \mathrm{kg})$ & $1945.17 \pm 19.56^{\mathrm{a}}$ & $542.78 \pm 4.869^{\mathrm{a}}$ & $547.42 \pm 9.510^{\mathrm{a}}$ & $371.9 \pm 13.48^{\mathrm{a}}$ \\
\hline $\mathrm{T}_{4}($ Clove $200 \mathrm{mg} / \mathrm{kg})$ & $1894.43 \pm 22.50^{\mathrm{ab}}$ & $544.50 \pm 9.330^{\mathrm{a}}$ & $513.56 \pm 12.26^{\mathrm{bc}}$ & $328.9 \pm 2.12^{b}$ \\
\hline $\mathrm{T}_{5}$ (Thyme $\left.100 \mathrm{mg} / \mathrm{kg}\right)$ & $1745.04 \pm 5.429^{\mathrm{d}}$ & $509.06 \pm 1.546^{\mathrm{c}}$ & $493.17 \pm 0.247^{\mathrm{d}}$ & $259.2 \pm 5.52^{\mathrm{e}}$ \\
\hline $\mathrm{T}_{6}$ (Thyme $200 \mathrm{mg} / \mathrm{kg}$ ) & $1813.25 \pm 17.20^{\mathrm{c}}$ & $528.22 \pm 4.570^{\mathrm{ab}}$ & $508.49 \pm 10.10^{b c}$ & $298.1 \pm 3.77^{\mathrm{cd}}$ \\
\hline LSD & 54.721 & 18.43 & 13.113 & 11.03 \\
\hline
\end{tabular}

Means of triplicates

Means having the same letter within each column are not significantly different at $p=0.05$ 


\section{Microbiological counts (log CFU/g) of EOS-kishk samples:}

Table (8) showed that the total viable bacterial count (TVBC) of Kishk samples of all treatments were significantly $(\mathrm{P}<0.05)$ compared with the control $\left(\mathrm{T}_{0}\right)$. The TVBC was decreased by increasing the levels of added essential oils. Kishk sample contained $100 \mathrm{mg}$ thyme/kg $\left(\mathrm{T}_{5}\right)$ had the lowest total viable bacterial count. TVBC of different Kishk samples were ranged from 5.64 to $7.64 \log$ CFU/g in the same line with Tamime et al. (2000) finding. The data in Table (8) showed that, all treatments of Kishk samples had lactic acid bacterial count lower than $\mathrm{T}_{0}$, however, there were no significant differences $(p<0.05)$ among all EOS-kishk samples in their lactic acid bacterial count. These results are in agreement with Özcan and Ekinci (2013) and Abd ElKhalek et al. (2016), they found that the phenolic compounds positively affected the growth and metabolism of lactic acid bacteria. Lactic acid bacterial counts were ranged from 5.13 to $6.03 \log \mathrm{CFU} / \mathrm{g}$ agree with Nurliyani et al. (2013).

Also, there were significant $(\mathrm{p}<0.05)$ differences in Streptococci count between EOS-kishk treatments and the control $\left(\mathrm{T}_{0}\right)$. While, the Streptococci counts were decreased with increasing the addition of the studied essential oils. Thyme essential oil recorded limited ability to stimulate the growth of Streptococci depending on the added concentration. Kishk sample containing thyme 200 $\mathrm{mg} / \mathrm{kg}\left(\mathrm{T}_{6}\right)$ had the lowest numbers of Streptococci. The coliform bacterial counts of all kishk treatments were significantly $(\mathrm{P}<0.05)$ lower than the control (Table 8) and ranged from 0.95 to $2.60 \mathrm{log} \mathrm{CFU} / \mathrm{g}$. The coliform count was clearly significantly decrease $(p<0.05)$ by increasing the levels of essential oils. Kishk sample containing clove essential oil $200 \mathrm{mg} / \mathrm{kg}\left(\mathrm{T}_{4}\right)$ had the lowest coliform counts. Data presented in Table (8) also showed that, yeasts and moulds were detected in all samples of tested products and their counts ranged from 1.74 to $2.67 \log \mathrm{CFU} / \mathrm{g}$. The results also showed close counts of yeasts and moulds in kishk samples.

The spore forming count of all EOS-kishk samples (Table 8 ) were significantly $(\mathrm{P}<0.05)$ compared with the control $\left(\mathrm{T}_{0}\right)$. While, EOS-kishk samples supplemented with essential oils recorded variable decrease in spore forming bacterial counts depending on the concentration of the essential oils added. These results are in harmony with those of Tamime et al. (2000), Gadallah and Hassan (2019) and El-Den (2020).

Table (8): Microbiological counts (log CFU/g) of kishk samples

\begin{tabular}{|c|c|c|c|c|c|c|}
\hline Treatments of kishk & $\begin{array}{c}\text { Total } \\
\text { bacterial } \\
\text { count }\end{array}$ & $\begin{array}{l}\text { Lactobacilli } \\
\text { count }\end{array}$ & $\begin{array}{l}\text { Streptococe } \\
\text { i count }\end{array}$ & $\begin{array}{l}\text { Coliform } \\
\text { bacteria }\end{array}$ & $\begin{array}{l}\text { Yeasts and } \\
\text { moulds }\end{array}$ & $\begin{array}{c}\text { Spore } \\
\text { forming } \\
\text { bacteria }\end{array}$ \\
\hline $\mathbf{T}_{0}($ Control) & $7.64 \pm 0.459^{\mathrm{a}}$ & $6.03 \pm 0.133^{\mathrm{a}}$ & $4.08 \pm 0.103^{\mathrm{a}}$ & $2.60 \pm 0.48^{\mathrm{a}}$ & $2.34 \pm 0.359^{\mathrm{ab}}$ & $5.04 \pm 0.083^{\mathrm{a}}$ \\
\hline$T_{1}($ Cinnamon $100 \mathrm{mg} / \mathrm{kg})$ & $6.22 \pm 0.200^{\mathrm{d}}$ & $5.50 \pm 0.320^{\mathrm{ab}}$ & $3.71 \pm 0.237^{\mathrm{b}}$ & $1.51 \pm 0.40^{\mathrm{bc}}$ & $2.42 \pm 0.252^{\mathrm{ab}}$ & $4.23 \pm 0.200^{\mathrm{bc}}$ \\
\hline $\mathrm{T}_{2}$ (Cinnamon $\left.200 \mathrm{mg} / \mathrm{kg}\right)$ & $6.82 \pm 0.337^{\mathrm{bc}}$ & $5.21 \pm 0.582^{\mathrm{b}}$ & $3.15 \pm 0.055^{\mathrm{cd}}$ & $1.11 \pm 0.36^{\mathrm{c}}$ & $1.74 \pm 0.208^{\mathrm{b}}$ & $3.88 \pm 0.100^{\mathrm{d}}$ \\
\hline$T_{3}($ Clove 100 mg/kg) & $6.19 \pm 0.214^{\mathrm{d}}$ & $5.47 \pm 0.266^{\mathrm{ab}}$ & $3.52 \pm 0.321^{\mathrm{b}}$ & $1.50 \pm 0.69^{\mathrm{bc}}$ & $2.67 \pm 0.208^{\mathrm{a}}$ & $4.17 \pm 0.149^{c}$ \\
\hline $\mathrm{T}_{4}($ Clove $200 \mathrm{mg} / \mathrm{kg})$ & $6.37 \pm 0.331^{\mathrm{cd}}$ & $5.30 \pm 0.575^{b}$ & $3.02 \pm 0.081^{\mathrm{d}}$ & $0.95 \pm 0.47^{\mathrm{c}}$ & $1.74 \pm 0.551^{\mathrm{b}}$ & $3.61 \pm 0.100^{\mathrm{e}}$ \\
\hline$T_{5}$ (Thyme 100 mg/kg) & $5.64 \pm 0.200^{\mathrm{e}}$ & $5.62 \pm 0.321^{\mathrm{ab}}$ & $3.50 \pm 0.320^{\mathrm{bc}}$ & $1.88 \pm 0.07^{\mathrm{ab}}$ & $2.81 \pm 0.153^{\mathrm{a}}$ & $4.43 \pm 0.200^{\mathrm{b}}$ \\
\hline$T_{6}$ (Thyme 200 mg/kg) & $6.94 \pm 0.170^{\mathrm{b}}$ & $5.13 \pm 0.086^{\mathrm{b}}$ & $2.85 \pm 0.100^{\mathrm{d}}$ & $1.06 \pm 0.31^{\mathrm{c}}$ & $1.81 \pm 0.737^{\mathrm{b}}$ & $3.82 \pm 0.115^{\mathrm{de}}$ \\
\hline LSD & 0.508 & 0.652 & 0.358 & 0.760 & 0.710 & 0.25 \\
\hline
\end{tabular}

Means of triplicates

Means having the same letter within each column are not significantly different at $p=0.05$

\section{Sensory evaluation of kishk samples:}

The flavor scores of different Kishk samples were ranged from 7.78 to 9.06 (Table 9). The lowest score of taste was given by Kishk samples $\left(\mathrm{T}_{3}\right)$ prepared from clove essential oil $(100 \mathrm{mg} / \mathrm{kg})$. The body and texture scores of different Kishk samples were ranged from 3.78 to 4.40. The lowest score of body and texture was given by Kishk samples $\left(\mathrm{T}_{2}\right)$ contained cinnamon essential oil (200 $\mathrm{mg} / \mathrm{kg}$ ). The appearance and color scores of different Kishk samples varied from 3.93 to 4.53 . The Kishk sample contained cinnamon essential oil $200 \mathrm{mg} / \mathrm{kg}\left(\mathrm{T}_{2}\right)$ recorded the lowest score of appearance and color. There were significant differences $(\mathrm{p}<0.05)$ in total scores between kishk from different treatments and the control except $\mathrm{T}_{5}$ (Table 8 ). Kishk containing thyme oil (100 $\mathrm{mg} / \mathrm{kg})\left(\mathrm{T}_{5}\right)$ gained the highest overall score followed by $\mathrm{T}_{6}$ sample. Besides, Kishk sample containing cinnamon or clove essential oil $(100 \mathrm{mg} / \mathrm{kg})$ had more overall acceptability scores than that contained 200 $\mathrm{mg} / \mathrm{kg}$ of the same EOS. Also, the highest score of all sensory evaluation given by control sample.

However, each essential oil has its own effect on organoleptic properties of final product, but scientific studies mainly reported that these EOS in specific concentration not only has positive effect on shelf-life of foods, but they can also improve organoleptic properties. 
Table (9): Sensory evaluation of kishk samples

\begin{tabular}{|c|c|c|c|c|}
\hline Treatments of kishk & Flavor & Body and Texture & $\begin{array}{c}\text { Appearance and } \\
\text { colour }\end{array}$ & Overall scores \\
\hline $\mathbf{T}_{0}$ (Control) & $9.06 \pm 0.77^{\mathrm{a}}$ & $4.40 \pm 0.61^{\mathrm{a}}$ & $4.53 \pm 0.62^{\mathrm{a}}$ & $18.00 \pm 1.317^{\mathrm{a}}$ \\
\hline $\mathrm{T}_{1}($ Cinnamon $100 \mathrm{mg} / \mathrm{kg})$ & $8.28 \pm 1.09^{\mathrm{bcd}}$ & $4.00 \pm 0.41^{\mathrm{bcd}}$ & $4.06 \pm 0.57^{\mathrm{bc}}$ & $16.34 \pm 1.221^{\mathrm{cd}}$ \\
\hline $\mathrm{T}_{2}($ Cinnamon $200 \mathrm{mg} / \mathrm{kg})$ & $7.84 \pm 0.63^{\mathrm{cd}}$ & $3.78 \pm 0.41^{\mathrm{d}}$ & $3.93 \pm 0.68^{\mathrm{c}}$ & $15.56 \pm 1.352^{\mathrm{d}}$ \\
\hline$T_{3}($ Clove $100 \mathrm{mg} / \mathrm{kg})$ & $7.78 \pm 0.91^{d}$ & $3.96 \pm 0.46^{\text {bcd }}$ & $4.25 \pm 0.58^{\mathrm{abc}}$ & $16.00 \pm 1.252^{\mathrm{cd}}$ \\
\hline $\mathrm{T}_{4}($ Clove $200 \mathrm{mg} / \mathrm{kg})$ & $7.81 \pm 0.75^{\mathrm{cd}}$ & $3.90 \pm 0.27^{\mathrm{cd}}$ & $4.09 \pm 0.46^{\mathrm{bc}}$ & $15.81 \pm 0.929^{\mathrm{d}}$ \\
\hline $\mathrm{T}_{5}($ Thyme $100 \mathrm{mg} / \mathrm{kg})$ & $8.75 \pm 0.93^{\mathrm{ab}}$ & $4.25 \pm 0.45^{\mathrm{ab}}$ & $4.37 \pm 0.59^{\mathrm{ab}}$ & $17.38 \pm 1.638^{\mathrm{ab}}$ \\
\hline $\mathrm{T}_{6}($ Thyme $200 \mathrm{mg} / \mathrm{kg})$ & $8.37 \pm 0.72^{\mathrm{bc}}$ & $4.18 \pm 0.66^{\mathrm{abc}}$ & $4.31 \pm 0.68^{\mathrm{abc}}$ & $16.88 \pm 1.489^{\mathrm{bc}}$ \\
\hline LSD & 0.590 & 0.338 & 0.421 & 0.932 \\
\hline
\end{tabular}

Means of triplicates

Means having the same letter within each column are not significantly different at $p=0.05$

\section{CONCLUSION}

The addition of essential oils clearly had lowering effect on coliform bacteria, spore forming bacteria, moulds and yeasts counts in the prepared Kishk product. Addition of essential oils to Kishk may be improved its health benefits, whereas, this product had high antioxidant activity, indicating that the product had potential health effect.

\section{REFERENCES}

Abd El-Khalek, A.B., H. S. El-Sayed, G. A. Ibrahim and K. El-Shafei (2016). Phenolic compounds, microbial content and sensory evaluation of symbiotic labneh containing ginger and probiotic. International Journal of Chem. Tech Research, 9 (2): $238-247$

Aguilar-González, A. E., E. Palou, and A. López-Malo (2015). Antifungal activity of essential oils of clove (Syzygium aromaticum) and/or mustard (Brassica nigra) in vapor phase against grey mold (Botrytis cinerea) in strawberries. Innovative Food Science and Emerging Technologies, 32: 181-185.

Alsaraf, S., Z. Hadi, W. Al-Lawati, A. Al Lawati and S. Khan (2020). Chemical composition, in vitro antibacterial and antioxidant potential of Omani Thyme essential oil along with in silico studies of its major constituent. J. King Saud Univ., Sci., 32(1): 1021-1028.

Anon, (2007). European Research on Traditional Foods. European Commission, Directorate General for Research, Brussels, Belgium, pp 4-14.

AOAC (2007). Official methods of analysis $\left(18^{\text {th }}\right)$.
Association of Official Agricultural Chemists, CH, Washington D.C., USA 34: 72-80.

AOAC (2000). Official Methods of Analysis Association of Official Analytical Chemists. $17^{\text {th }}$ Wisconsin: George Banta Co. Inc.

APHA (1992). American public association standard method for the examination of dairy products $\left(16^{\text {th }}\right)$ Wasgington DC, USA.

Burt, S. (2004). Essential oils: Their antibacterial properties and potential applications in foods A review. International Journal of Food Microbiology, 94(3): 223-253.

Carvalho, I. T., B. N. Estevinho and L. Santos (2016). Application of microencapsulated essential oils in cosmetic and personal healthcare products-a review. International Journal of Cosmetic Science, 38: 109-119.

Chen, H., X. Hu, E. Chen, S. Wu, D. McClements, S. Liu, B. Li and Y. Li (2016). Preparation, characterization, and properties of chitosan films with cinnamaldehyde nanoemulsions. Food Hydrocolloids, 61: 662-671.

Chen, X., L. L. Ren, J. Qian, J. Fan and B. Du (2017). Effects of clove essential oil and eugenol on quality and browning control of fresh-cut lettuce. Journal of Agricultural and Food Chemistry, 214: 432-439.

Clark, S., M. Costello, M. drak and F. Body-Felt (2009). The sensory evaluation of dairy products. Springer.

Demirci, A. S., I. Palabiyik, S. Ozalp and G. S. Tirpanci (2019). Effect of using kefir in the formulation of traditional Tarhana. Food Science and Technology, 39(2): 358-364. 
El-Den E. A. (2020). Quality attributes of probiotic kishk supplemented with plant extracts. Egyptian Journal of Dairy Science, 48: 55-63.

Erkan, H., S. Çelik, B. Bilgi and H. Köksel (2006). A new approach for the utilization of barley in food products: Barley tarhana. Food Chemistry, 97: 12-18.

EU (European Union), (2008). Commission regulation (EU) No 1333/2008 of 16 December 2008 of the European parliament and of the council on food additives. Off. J. Eur. Union L354, 16

FDA (2002). Bacteriological Analytical Manual. $9^{\text {th }}$ Ed., AOAC International, Arlington, VA, USA.

Gadallah, M. G. E. and M. F. Y. Hassan (2019). Quality properties of kishk (a dried fermented cerealmilk mixture) prepared from raw materials. Journal of the Saudi Society of Agricultural Sciences, 18: 95-101

Grigore, A., I. Paraschiv, S. Colceru-Mihul, C. Bubueanu, E. raghici and M. Ichim (2010). Chemical composition and antioxidant activity of Thymus vulgaris L. volatile oil obtained by two different methods. Romanian Biotechnological Letters, 15: 5436-5443

Han,Y. Y., M. Yu and L. J. Wang (2018). Physical and antimicrobial properties of sodium alginate/carboxymethyl cellulose films incorporated with cinnamon essential oil, Food Packag. Shelf Life, 15: 35-42.

Hasheminejad, N., F. Khodaiyan and M. Safari (2019). Improving the antifungal activity of clove essential oil encapsulated by chitosan nanoparticles, Food Chemistry, 275: 113-122,

Hudaib, M. and T. Aburjai (2007). Volatile components of Thymus vulgaris L. from wild growing and cultivated plants in Jordan. Flavour and Fragrance Journal, 22: 322-327.

IDF (1985). Milk and milk products. Enumeration of coliforms-colony counts technique and most probable number technique at $30^{\circ} \mathrm{C}$. FIL-IDF 73A International Dairy Federation Brussels, Belgium.

IDF (1987). Milk, cream, fermented milks, and evaporated milk-total solids. FIL-IDF 21B, International Dairy Federation Brussels, Belgium.

IDF (1997). Yoghurt. Enumeration of characteristic microorganisms. Colony count technique at $37^{\circ} \mathrm{C}$. FIL-IDF $117 \mathrm{~B}$ International Dairy Federation Brussels, Belgium.

IDF (1993). Milk. Protein determination, determination of nitrogen content. Kjeldahl method and calculation of crude protein content. Standard FIL-IDF 20B. International Dairy Federation Brussels, Belgium.

Jayawardena, B. and R. Smith (2010). Superheated water extraction of essential oils from (Cinnamomum zeylanicum L.). Phytochemistry Annales, 21: 470-472.

Jeon, Y., S. Lee, Y. Yanga and H. Lee (2017). Insecticidal activities of their components derived from the essential oils of Cinnamomum sp. barks and against Ricania sp.). Homoptera:
Ricaniidae), a newly recorded pest. Pest Management Science, 73: 2000-2004.

Jiang, Y., D. Wang, F. Li, D. Li and Q. Huang (2020). Cinnamon essential oil Pickering emulsion stabilized by zein-pectin composite nanoparticles: Characterization, antimicrobial effect and advantages in storage application. International Journal of Biological Macromolecules, 148: 1280-1289.

Kaliamurthi, S., G. Selvaraj, L. Hou, Z. Li, Y. Wei, K. $\mathrm{Gu}$ and D. Wei (2019). Synergism of essential oils with lipid based nanocarriers: emerging trends in preservation of grains and related food products. Grain \& Oil Science and Technology, 2(1): 21-26.

Kett, A. P., V. Chaurin, S. M. Fitzsimons, E. R. Morris, J. A. O'Mahony and M. A. Fenelon (2013). Influence of milk proteins on the pasting behavior and microstructural characteristics of waxy maize starch. Food Hydrocolloids, 30: 661-671.

Kumar, L., M. Brennan, H. Zheng and C. Brennan (2018). The effects of dairy ingredients on the pasting, textural, rheological, freeze-thaw properties and swelling behaviour of oat starch. Food Chemistry, 245: 518-524.

Lee, S. C., J. H. Kim, S. M. Jeong, D. R. Kim, J. U. Ha, K. C. Nam and D. U. Ahn (2003). Effect of farinfrared radiation on the antioxidant activity of rice hulls. Journal of Agricultural and Food Chemistry, 51: 4400-4403.

Mahmoudi, R., P. Zare, P. Hassanzadeh and S. Nosratpour (2014). Effect of Teucrium polium essential oil on the physicochemical and sensory properties of probiotic yoghurt. Journal of Food Processing and Preservation, 38(3): 880-888.

Marino, M., C. Bersani and G. Comi (2001). Impedance measurements to study the antimicrobial activity of essential oils from Lamiaceae and Compositae. International Journal of Food Microbiology, 67(3):187-195.

Marshall, R. T. (1992). Standard Methods for the Examination of Dairy Products. $16^{\text {th }}$ ed. Am. Publ. Health Assoc., Washington, DC.

Millezi, A. F. (2012). Ação de oleos essenciais sobre biofilmes formados por Staphylococcus aureus, Escherichia coli. Universidade Federal de Lavras, 1-112.

Noori, S., F. Zeynali and H. Almasi (2018). Antimicrobial and antioxidant efficiency of nanoemulsion-based edible coating containing ginger (Zingiber officinale) essential oil and its effect on safety and quality attributes of chicken breast fillets. Food Control, 84: 312320.

Nurliyani, I., Y. Indratiningsihand Rahmayanti (2013). Kualitas Kishk Yang Dibuat Dari Campuran Yogurt Dan Tepung Sagu (Metroxylon sp). In: Peran Teknologi dan Industri Panganuntuk Percepatantercapainya Kedaulatan Pangan Indonesia, 26-29 Agustus, 2013 (Cited from Abou-Zeid N.A., 2016. Review of Egyptian 
cereal-based fermented product (Kishk). Int. J. Agric. Innov. Res., 4(4): 600-609.

Oliveiraa, R. C., M. Carvajal-Morenoa, B. Correab and F. Rojo-Callejas (2020). Cellular, physiological and molecular approaches to investigate the antifungal and anti-aflatoxigenic effects of thyme essential oil on Aspergillus flavus. Food Chemistry, 315: 126096.

Özcan, E. and F. Y. Ekinci (2013). Mechanisms underlying the effects of lactic acid bacteria (LAB) on phenolic compounds. International Conference on Food and Biosystems Engineering, May 30June 2, Skiathos Islands, Greece., vol. 1: 236-247.

Ozogul, Y., E. Kuley, Y. Ucar and F. Ozogul (2015). Antimicrobial impacts of essential oils on food borne pathogens. Recent Patents on Food, Nutrition \& Agriculture, 7(1): 53-61.

Page, A. L. (1982). Methods of soil analysis. Part 2: Chemical and microbiological properties, $\left(2^{\text {nd }}\right)$. Am. Soc. At Agron. Inc. Soil Sci. Soc. Am., Madison, Wisconsin, USA.

Poutanen, K., L. Flander and K. Katina (2009). Sourdough and cereal fermentation in a nutritional perspective. Food Microbiology, 26: 693-699.

Pozzatti, P., E. S. Loreto, P. G. Lopes, M. L. Athayde, J. M. Santurio and S. H. Alves (2009). Comparison of the susceptibilities of clinical isolates of Candida albicans and Candida dubliniensisto essential oils. Mycoses, 53: 512.

Probst, I. D. S. (2012). Atividade Antibacteriana De ÓleosEssenciais E Avaliação De Potencial Sinérgico. Universidade Estadual de São Paulo Retrieved from http://www.ibb.unesp.br/ posgrad/teses/bga_me_2012_isabella_probst.p df

Rahmawati, I. S. and W. Suntornsuk (2016). Effects of fermentation and storage on bioactive activities in milks and yoghurts. Procedia Chemistry, 18: 53-62.

Ramadan, M. F., M. M. Asker and M. Tadros (2013). Lipid profile, antiradical power and antimicrobial properties of Syzygium aromaticum oil. Grasas Y Aceites, 64: 509520.

Rota, M. C., A. Herrera, R. M. Martínez, J. A. Sotomayor and M. J. Jordán (2008). Antimicrobial activity and chemical composition of Thymus vulgaris, Thymuszygis and Thymus hyemalis essential oils. Food Control, 19: 681-687.

Sadrizadeh N., S. Khezri, P. Dehghan and R. Mahmoudi (2018). Antibacterial Effect of Teucrium polium Essential Oil and Lactobacillus casei Probiotic on Escherichia coli O157: H7 in Kishk. Applied Food Biotechnology, 5 (3): 131-140.

Saricaoglu, F. T. and S. Turhan (2019). Performance of mechanically deboned chicken meat protein coatings containing thyme or clove essential oil for storage quality improvement of beef sucuks. Meat Science, 158: 107912.
Schulz, H., R. Quilitzsch and H. Kruger (2003). Rapid evaluation and quantitative analysis of thyme, origano and chamomile essential oils by ATRIR and NIR spectroscopy. Journal of Molecular Structure, 661-662, 299-306.

Shevade, A. V., Y. C. O'Callaghan, N. M. O'Brien, T. P. O'Connor and T. P. Guinee (2019). Development of a dehydrated fortified food base from fermented milk and parboiled wheat, and comparison of its composition and reconstitution behavior with those of commercial dried dairy-cereal blends. Food Science \& Nutrition, 7: 3681-3691.

Şimşek, Ü. G., M. Çiftçi, G. Doğan and M. Özçelik (2013). Antioxidant activity of cinnamon bark oil (Cinnamomum zeylanicum L.) in Japanese quails under Thermo neutral and heat stressed conditions. Ankara Universitesi Veteriner Fakultesi Dergisi, 19(5): 889-894.

Tamime, A. Y., M. N. Barclay, R. Amarowicz and D. McNulty (1999). Kishk-a dried fermented milk/cereal mixture. 1 Composition of gross components, carbohydrates, organic acids, and fatty acids. Le Lait, 79: 317-330.

Tamime, A. Y., D. D Muir, M. N. Barclay, M. Khaskheli and D. Mcnulty (1997). Laboratorymade Kishk from wheat, oat and barley: 2 . Compositional quality and sensory properties. Food Res. Int., 30: 319-326.

Temiz, A. and T. Pirkul (1991). Chemical and sensory properties of tarhana produced in different compositions. Food, 16: 7-13.

Tiessen, H. and J. O. Moir (1993). Characterization of available $\mathrm{P}$ by sequential extraction. In M.R. Carter (ed.) Soil Sampling and Methods of Analysis. Lewis Publishers, Boca Raton, Fl. Pp. 75-86.

Villanueva, M. T. O., A. D.Marquina, B. A. de Diego and G. B. Abellan (2000). Sodium, Potassium, Calcium and Magnesium Content in Breakfast Cereals: Products Highly consumed by the Spanish Population', European Food Research and Technology, 211: 352-354.

Wani, A., P.Singh, M. Shah, U. Schweiggert-Weisz, K. Gul and I. Wani (2012). Rice starch diversity: Effects on structural, morphological, thermal, and physicochemical properties-A review. Comprehensive Reviews in Food Science and Food Safety, 11: 417-436.

WFP (World Food Program). (2015). Technical specifications for the manufacture of: Super Cereal plus corn soya blend. Version 15.1. https://documents.wfp.org/stellent/groups/publi c/documents/manualguideproced/wfp281226.p df Accessed 18 May2018.

Xing, F., H. Hua, J. N. Selvaraj, Y. Zhao, L. Zhou and $X$. Liu (2014). Growth inhibition and morphological alterations of Fusarium verticillioides by cinnamon oil and cinnamaldehyde. Food Control, 46: 343-350.

Yu, D., Y. Xu, Q. Jiang and W. Xia (2017). Effects of chitosan coating combined with essential oils on quality and antioxidant enzyme activities of 
grass carp (Ctenopharyngodon idellus) fillets stored at $4^{\circ} \mathrm{C}$. International Journal of Food

Science and Technology, 52(2): 404-412.
Zhang, H., J. Wu and X. Guo (2016). Effects of antimicrobial and antioxidant activities of spice extracts on raw chicken meat quality. Food Science and Human Wellness, 5(1): 1-10.

\section{إستخدام زيوت القرفة والقرنفل والزعتر كمواد مضادة للميكروبات ومركبات نشطة بيولوجياً في



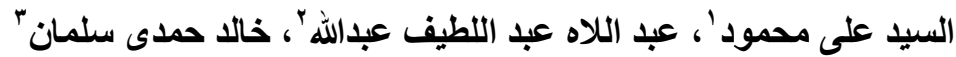

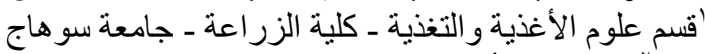

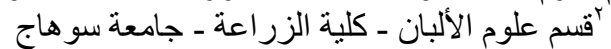 \\ "قسم الألبان- كلية الزر البان - كلية - جامعة الأزهر بأسيوط}

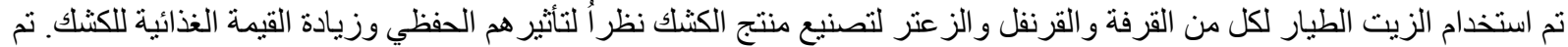

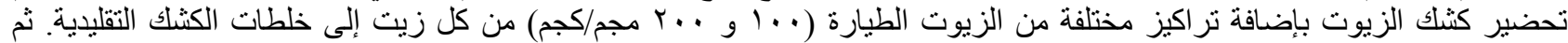

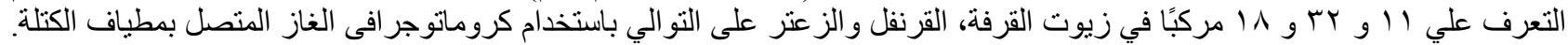

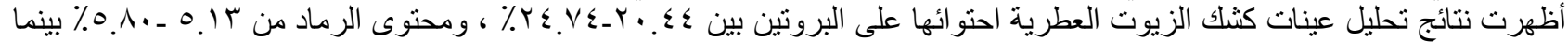

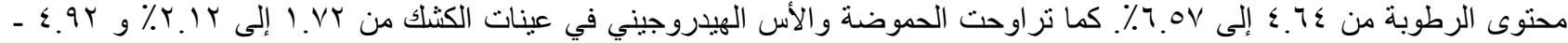

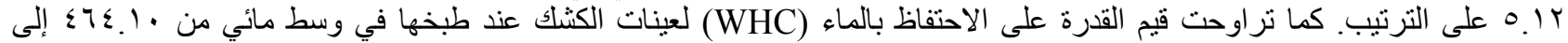

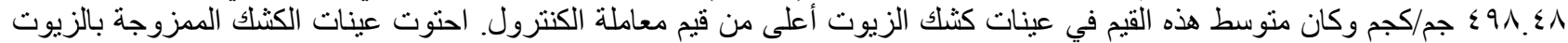

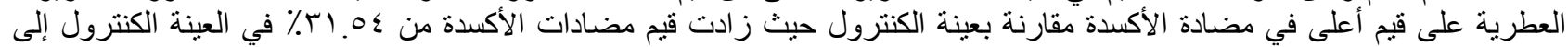

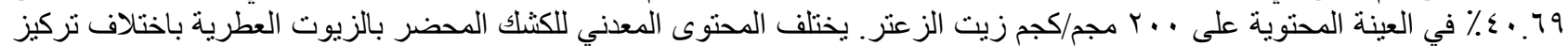

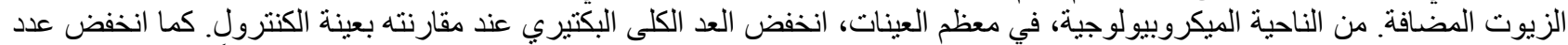

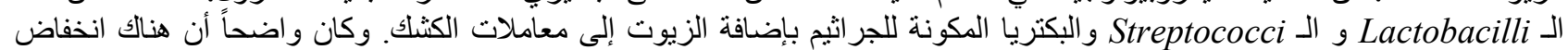
ملحوظ في أعداد بكتريا القولون وكذلك الخمائر و الفطريات في العينات المعاملة بالزيوت العطرية العية عند مقارنتها بعينة الكنترول. 